удК 341.018

\title{
ПРИНЦИП КОМПЛЕМЕНТАРНОСТІ У МІЖНАРОДНОМУ КРИМІНАЛЬНОМУ ПРАВІ
}

Постановка проблеми. Останніми десятиліттями однією з юридичних сфер, що швидко розвиваються, стало транснаціональне кримінальне право як галузь міжнародного кримінального права. Дана обставина обумовлена цілим рядом причин дійсно планетарного характеру: процеси соціально-економічної й певною мірою політичної глобалізації, зростання транснаціональної злочинності, збільшення числа локальних і регіональних конфліктів, ескалація терористичної загрози тощо. Сплеск зацікавленості до теоретичних і правозастосовних проблем транснаціонального кримінального права пов'язаний також із прийняттям Римського статуту та заснуванням Міжнародного кримінального суду в 1998 р. [3], з початком його діяльності як постійного органу міжнародної юстиції, а також з ухваленням міжнародних конвенцій, спрямованих на співробітництво у сфері боротьби з окремими транснаціональними злочинами (тероризм, піратство, корупція, торгівля людьми, відмивання грошей, екоцид, кіберзлочини тощо) та Конвенції ООН проти транснаціональної організованої злочинності від 15 листопада 2000 р. [1].

Метою статті є вивчення принципу комплементарності юрисдикцій у міжнародному кримінальному праві, його формування, концепція, втілення у міжнародно-правових актах та діяльності органів міжнародної юстиції у зв’язку зі зростанням транснаціональної злочинності.

Аналіз останніх досліджень. Відправною точкою для сучасних доктринальних пошуків являються класичні праці знаних вчених науки міжнародного кримінального права, як М. Бассиуни, Н. Бойстера, Г. Верле, А. Кассезе, Ф. Сэндса, У. Шабаса та інших. У статті зроблена спроба проаналізувати концептуальні підходи до розуміння принципу комплементарності, що сформульовані у наукових працях як закордонних так й вітчизняних вчених, зокрема, С. Вільямса, Ф. Джессбергера, Н. Дрьоміної, Р. Ренні, С. Рингерта, Н. Сафарова, О. Солера, С. Стахна, О. Трикоз, К. Хеллера, У. Шабаса. Значний інтерес у зазначеній проблематиці викликають праці німецького професора Герхарда Верле [12], який концептуально розглядає принцип комплементарності та його переваги як основу взаємовідносин між міжнародною та національною кримінальними юрисдикціями, як модель діяльності Міжнародного кримінального суду.

Виклад основного матеріалу. Із заснуванням на початку 90 -х pp. минулого століття міжнародних кримінальних трибуналів $a d$ hoc для переслідування осіб, винних у здійсненні тяжких міжнародних злочинів на території колишньої республіки Югославії (далі - МТКЮ) і Руанди (далі - МКТР) та Міжнародного кримінального суду (далі - МКС) у 1998 р. почали формуватися взаємовідносини національних й міжнародних органів юстиції, які будувалися на принципі комплементарності (доповнюваності) юрисдикцій. Як відмітив Н.А. Сафаров, «вже у самому початку процесу заснування міжнародних трибуналів було зрозуміло, що концепція спів- 
робітництва з ними повинна відрізнятися від концепції міждержавного співробітництва», оскільки принципи національних правових систем не могли бути механічно перенесені до сфери взаємовідносин держав з міжнародними трибуналами $[16$, c. 434$]$.

Принцип комплементарності як основа здійснення юрисдикції органами правосуддя - новий вид взаємин національної та міжнародної юрисдикцій. Добровільне визнання можливості обмеження суверенітету незалежної держави (у випадках, передбачених положеннями про прийнятність) є особливим, унікальним проявом державної правової свідомості й, безумовно, потребує часу для трансформації сформованих стандартів недоторканності національного суверенітету, зокрема у сфері кримінальної юстиції, на користь об'єднання зусиль членів міжнародної спільноти у боротьбі зі злочинністю. Відповідно до принципу комплементарності, як зазначає Г. Верле, «міжнародна юрисдикція не заміщає національну юрисдикцію, навіть відносно «ключових» злочинів, а просто доповнює ії. Національна юрисдикція, як правило, має перевагу, крім випадків, коли держава не бажає чи не здатна вести розслідування чи порушувати кримінальне переслідування належним чином» [12, с. 113]. Пріоритетна роль у кримінальному переслідуванні осіб, що здійснили міжнародні злочини, у тому числі й транснаціональні, належить внутрішньодержавним судовим органам. Щодо ролі Міжнародного кримінального суду в цих відносинах, то, як слушно відмічає Н.В. Дрьоміна, Римський Статут «не дає оцінки чи характеристики ніякій національній системі кримінального переслідування як такій. Тому Суд буде залишатися нейтральним у своїй взаємодії з державами» [14, с. 185].

Принцип комплементарності концептуально пов'язаний з міжнародною та національною юрисдикціями, взаємовідносинами між ними у «горизонтальному» та «вертикальному» аспектах [16]. Юридична модель «горизонтальних» і «вертикальних» взаємовідносин національних і міжнародних судових органів була запропонована Міжнародним трибуналом по колишній Югославії у 1997 р. у Рішенні по справі Т. Блажича [10]. У своєму рішенні Трибунал підкреслив, що «зазвичай індивіди, які являються суб'єктами суверенної компетенції держав, можуть бути судимими лише національними судами. Якщо ж національний суд має намір переслідувати особу, що підпадає під юрисдикцію іншої держави, як правило, це базується на договорах про правове співробітництво (treaties of judicial cooperation) або, якщо таких договорів немає - на добровільному міждержавному співробітництві (voluntary interstate cooperation). Таким чином, відносини між національними судами різних держав являються «горизонтальними» по своїй природі. У 1993 р. Рада Безпеки вперше заснувала міжнародний кримінальний трибунал, наділений юрисдикцією над особами, що проживають у суверенних державах, будь-то держави, що входили до складу колишньої Югославії, або треті країни, що погодилися з приматом міжнародного трибуналу над національними судами <...> Таким чином був встановлений «вертикальний» зв’язок, у крайньому разі в частині, що стосується судових повноважень міжнародного трибуналу<...>» [16, с. 434-435]. 3 цього часу у міжнародно-правовій доктрині усталено закріпилось розмежування «горизонтального» (inter-state) i «вертикального» (supra-state) співвідношення юрисдикції національних і міжнародних кримінальних судів. 
Як було відмічено, «горизонтальний» взаємозв'язок судових органів держав згідно з концепцією субсидіарності передбачає перевагу територіальної та екстратериторіальної юрисдикції перед універсальним принципом. С. Рингерт називає iï ще «горизонтальною комплементарністю» [28, с. 5], а Ф. Джессбергер пише, що «не дивлячись на те, що горизонтальний взаємозв'язок між юрисдикцією двох держав відрізняється від вертикальних взаємовідносин між державою і Міжнародним кримінальним судом, принцип комплементарності може бути поступово впроваджений у практику міждержавних відносин» [23, с. 213].

Щодо «вертикальних" взаємовідносин судів національного і міжнародного рівня, то у цьому відношенні в доктрині не існує єдиного погляду, однак на думку окремих дослідників, субсидіарний характер міжнародної кримінальної юрисдикції обумовлений введенням принципу комплементарності Міжнародного кримінального суду. Як пише Г.Верле, «можна виділити дві основні моделі приписування юрисдикції - залежно від того чи володіють перевагою національні чи міжнародні суди. Ці моделі доповнюються концепцією комплементарності, яка являє собою організаційний принцип sui generis» [12, с. 111].

В наш час у міжнародно-правовій практиці виявлено три основних моделі взаємовідносин органів національного і міжнародного кримінального правосуддя. Статут Нюрнберзького трибуналу встановив виключну юрисдикцію Суду над головними воєнними злочинцями Другої світової війни 3-поміж вищих посадових осіб Німеччини. Відносно інших осіб, винних у здійсненні тяжких злочинів під час війни, юрисдикція визнавалась за державами, де були здійсненні відповідні злочини [30, с. 21].

На відміну від Нюрнберзької моделі, статути трибуналів ad hoc встановлюють «паралельну юрисдикцію» - термін, який використовується для позначення як юрисдикції самого трибуналу, так й можливостей національних судових органів здійснювати юрисдикцію. Зокрема, у Статуті Міжнародного кримінального трибуналу по колишній Югославії (далі - МТКЮ) [4] зазначається пріоритет юрисдикції Трибуналу над національними судами: «Юрисдикція Міжнародного трибуналу має пріоритет стосовно юрисдикції національних судів. На будь-якому етапі судового розгляду Міжнародний трибунал може офіційно просити національні суди передати провадження по справі Міжнародному трибуналу у відповідності із Статутом» (ст. 9). Також Статут закріплюе зобов'язання держав співпрацювати з Трибуналом, здійснюючи різні процесуальні заходи, зокрема: пізнавання та встановлення місцеперебування осіб; зняття показів свідків і провадження дій по збору доказів; вручення документів; арешт і затримання осіб; видачу і передачу обвинувачених Міжнародному трибуналу (ст. 29).

Аналогічні положення містяться у Статуті Міжнародного кримінального трибуналу по Руанді (ст. 8), статутах Спеціального суду по Сьерра-Леоне (ст. 8), Спеціального трибуналу по Лівану (ст. 4), а також у Статуті Міжнародного остаточного механізму для кримінальних трибуналів (ст. 5), заснованого Радою Безпеки у 2010 p. [7].

Однак, паралельна юрисдикція, як вона закріплена в установчих актах міжнародних кримінальних трибуналів ad hoc, далеко не досконала з тої причини, 
що трибунали мають особливий правовий статус, що випливає з їх заснування на основі резолюцій Ради Безпеки як підвідомчих органів Ради і як наслідок цього, вони являються обов'язковими для країн-учасниць ООН. Пріоритет, яким були наділені трибунали, став причиною гострої полеміки, оскільки, на думку держав, розмиває поняття державного суверенітету. Правомірність створення трибуналів $a d h o c$ на підставі резолюцій Ради Безпеки $\mathrm{OOH}$ розглядалась і до цього часу обговорюється в закордонній міжнародно-правовій літературі [13; $15 ; 22 ; 26]$.

Принципово новою формою співвідношення міжнародної та національної кримінальної юрисдикції стала формула комплементарності, прописана у Статуті Міжнародного кримінального суду. Римський Статут створив модель юрисдикції, яка не узгоджується ні з однією з наявних моделей національної кримінальної юрисдикції, ні з наявних в рамках трибуналів $a d$ hoc міжнародною кримінальною юрисдикцією: в його основі лежить визнання концепції Міжнародного кримінального суду як органу, що доповнює національні судові органи. Комплементарність являється фундаментальним принципом, на якому будується кореляція правових порядків Міжнародного кримінального суду і держав-учасниць Статуту. Принцип додатковості встановлює, що юрисдикція МКС вводиться тільки у тому випадку, коли національні правові системи не можуть чи не бажають здійснювати юрисдикцію. Таким чином, у випадках збігу юрисдикцій між органом національної юстиції й Міжнародним кримінальним судом, перший з них, у принципі, має пріоритет. Міжнародний кримінальний суд не ставить за мету підміняти національні суди та діє тільки тоді, коли вони не діють.

Із самого початку роботи над розробкою Статуту Міжнародного кримінального суду з 1994 р. у рамках Підготовчого Комітету Комісії міжнародного права відбувалось обговорення майбутньої формули комплементарності [8]. При цьому враховувались дві основні позиції: перша - презумпція державного суверенітету, яка означає, що Суд не повинен втручатися у випадку ефективного і добросовісного національного кримінального переслідування, а також друга - встановлення пріоритету юрисдикції Міжнародного кримінального суду над національною юрисдикцією. При цьому у своїй доповіді по питанню заснування Міжнародного кримінального суду, Комітет підкреслював, що в наміри Комісії міжнародного права i Комітету не входила заміна національних судових органів Судом при веденні кримінального провадження, проте, і юрисдикція Суду не повинна була б стати просто остаточною [17].

Необхідний консенсус був досягнутий у 1997 р. щодо наступного формулювання: «Суд не повинен здійснювати юрисдикцію відносно злочину, за виключенням випадків, коли держава не в змозі чи не бажає проводити розслідування чи кримінальне переслідування" [34, с. 608]. Вона й була запропонована учасникам Римської конференції 1998 р. і прийнята без суттєвих змін. Більшість заоржонних вчених-правознавців підкреслюють, що Міжнародний кримінальний суд не володіє якоюсь перевагою стосовно юрисдикції національних судів, а функціонує відповідно до принципу комплементарності [25; $32 ; 19 ; 31]$.

Принцип комплементарності заявлений вже в Преамбулі Римського статуту як основа юрисдикції постійного Міжнародного кримінального суду. У Преамбулі 
(п. 4) підтверджується, що «найсерйозніші злочини, які викликають стурбованість усієї міжнародної спільноти, не мають залишатися безкарними та що їх дійове переслідування має бути забезпечене як заходами, вжитими на національному рівні, так і активізацією міжнародної спільноти». Далі висловлюється рішучість (п. 9) «заснувати незалежний постійний Міжнародний кримінальний суд, зв'язаний із системою Організації Об'єднаних Націй, який має юрисдикцію щодо найсерйозніших злочинів, які викликають стурбованість усього міжнародного співтовариства». Разом з тим у Преамбулі (п. 6) містить нагадування про те, «що обов'язком кожної держави є здійснення ії кримінальної юрисдикції над особами, котрі несуть відповідальність за вчинення міжнародних злочинів», а в п. 10 підкреслюється, що «Міжнародний кримінальний суд, заснований на підставі даного Статуту, доповнює національні органи кримінальної юстиції». У такий спосіб у Преамбулі Статуту проголошена необхідність ефективного сполучення національної та міжнародної юрисдикцій щодо міжнародних злочинів.

Детальніше реалізація принципу комплементарності юрисдикцій викладена у ст. 1 «Суд», ст. 17 «Питання прийнятності», ст. 18 «Попередні постанови, що стосуються прийнятності», ст. 19 «Протести відносно юрисдикції Суду чи прийнятності справи до провадження», ст. 20 «Ne bis in idem» та ст. 53 «Початок розслідування».

Згідно ст. 1 Міжнародний кримінальний суд «доповнює національні системи кримінального правосуддя», а в ст. 17 визначені чотири підстави, відповідно до яких Суд може встановити, чи прийнятна справа до провадження. Зокрема, у ст. 17 йдеться: «Суд визначає, що справа не може бути прийнята до провадження в тих випадках, коли: а) дана справа розслідується чи щодо неї держава, яка має стосовно неї юрисдикцію, порушила кримінальне переслідування, за винятком випадків, коли ця держава не бажає чи не здатна вести розслідування або порушити кримінальне переслідування належним чином; b) справа розслідувана державою, що має юрисдикцію щодо неї, і ця держава вирішила не порушувати щодо особи, якої це стосується, кримінального переслідування, за винятком випадків, коли це рішення стало результатом небажання чи нездатності держави порушити кримінальне переслідування належним чином; с) особа, якої це стосується, уже була суджена за поведінку, що є предметом даної заяви, і проведення судового розгляду Судом не дозволено на підставі п. 3 ст. 20 ; d) справа не є досить серйозною, щоб виправдувати подальші дії з боку Суду (1). При цьому юрисдикція Міжнародного кримінального суду тлумачиться від противного, визначаючи обставини, які необхідні для здійснення юрисдикції Судом.

Дані умови слід розглядати у сукупності, тобто вони всі повинні бути дотримані для того, щоб Суд міг прийняти справу до розгляду. Пункти 2 та 3 ст. 17 визначають критерії небажання і нездатності держави здійснювати судовий розгляд на національному рівні. Для визначення небажання держави такими критеріями виступають: судовий розгляд проводиться з метою обмежити відповідну особу від кримінальної відповідальності; мала місце необгрунтована затримка з проведенням судового розгляду, яка несумісна з наміром передати відповідну особу правосуддю; компетентний внутрішньодержавний судовий орган не являється незалежним і неупередженим. Як критерій, який визначає нездатність держави здійснити 
судове переслідування, відмічається повний або суттєвий розвал чи відсутність судової системи, коли держава не має можливості вести судову процедуру.

Наступний прояв принципу комплементарности зустрічаємо у ст. 18 Статуту. Вона вимагає, щоб перед тим, як справа буде розглядатися у Суді з ініціативи Прокурора, він повідомив всі держави, що беруть участь у Статуті, й ті держави, які зазвичай здійснювали б юрисдикцію відносно даних злочинів. Тільки у випадку звернення Ради Безпеки ООН (ст. 13 п. b) нотифікація не вимагається. В усіх інших випадках держава, яка має юрисдикцію, може інформувати Суд, що вона розслідувала чи розслідує справу. У цьому випадку Прокурор передає розслідування у компетенцію держави, за виключенням тих випадків, коли Палата попереднього провадження дозволяє проведення розслідування Прокурору.

Порядок подачі протестів відносно прийнятності справи до провадження Судом визначено у ст. 19, згідно зі ст. 20 виключається дублювання кримінального переслідування і судочинства на національному і міжнародному рівнях, а згідно зі ст. 53 (п. 2) являється недопустимим розслідування без достатніх підстав для початку кримінального переслідування. Принцип комплементарності найбільш яскраво проявляється на першому етапі судового розгляду, яким являється порушення розслідування і визначення прийнятності справи до провадження у Суді. Ряд положень, що конкретизують визначення прийнятності справи до провадження Судом містяться також у Правилах процедури і доказування МКС (Глава 3) [9].

Згідно зі ст. 13 Статуту існують наступні правові підстави для здійснення юрисдикції Судом: а) внаслідок передачі ситуації державою-учасницею; b) у випадку передачі ситуації Радою Безпеки ООН на підставі Глави VII Статуту ООН; с) за ініціативою Прокурора відповідно до ст. 15. При цьому право proprio motu Прокурора надає останньому широкі можливості для порушення судового провадження, однак для їх реалізації необхідна санкція Палати попереднього провадження (ст. 15). На цей час кілька держав-учасниць Римського Статуту передали на розгляд Суду ситуації, пов’язані з подіями, що відбулися на їх території - Республіка Уганда, Демократична Республіка Конго, Центральноафриканська Республіка, Республіка Малі («selfreferral» states). Рада Безпеки ООН передала Суду ситуацію в регіоні Дарфур (Судан) і в Лівії. Насамкінець, Палата попереднього провадження санкціонувала Прокурору почати розслідування за власною ініціативою у контексті ситуації у Республіці Кенії, Республіці Кот-Д’Івуарі та Республіці Грузії

Наявність розслідування чи проведення судового розгляду на національному рівні не завжди буде автоматично виключати прийнятність справи. Згідно з принципом комплементарності, в особливих випадках Міжнародний кримінальний суд самостійно визначає критерій бажання і здатності вести розслідування чи кримінальне переслідування саме належним чином. В уже згаданих ситуаціях по Кенії, Лівії та Кот-Д’Івуару, Палата попереднього провадження Суду використала формулу про прийнятність «same person/same conduct» («ця сама людина/це ж саме

${ }^{1} 27$ января 2016 г. Палата предварительного производства уполномочила Прокурора МУС начать расследование в отношении преступлений, подпадающих под юрисдикцию суда, предположительно совершенные в районе Южной Осетии с 1 июля по 10 октября 2008 г. URL: https://www.icc-cpi.int/en_menus/icc/structure 
діяння»). Дана формула застосовується Судом для оцінки того, чи дійсно держава приймає належні та конкретні заходи для здійснення кримінального переслідування особи у зв'язку з тими самими діяннями, які являються підставою для порушення судочинства в Міжнародному кримінальному суді незалежно від їх кримінально-правової кваліфікації в країні.

Аналогічне трактування принципу додатковості (комплементарності) ми знаходимо в конвенційних нормах щодо сфери транснаціонального кримінального права. Зокрема у Конвенції ООН проти транснаціональної організованої злочинності 2000 р. [1] у ст. 15 «Юрисдикція» п. 1 зазначається, що «кожна держава-учасниця вживає таких заходів, які можуть знадобитися для того, щоб установити свою юрисдикцію щодо злочинів, визнаних такими відповідно до статей 5, 6, 8 і 23 цієї Конвенції», а п. 6 цієї ж статті визначає: «без шкоди для норм загального міжнародного права ця Конвенція не виключає здійснення будь-якої кримінальної юрисдикції, встановленої державою-учасницею відповідно до її внутрішнього законодавства». Щодо злочину тероризму, то, зокрема, в Конвенції Ради Європи про запобігання тероризму від 16 травня 2005 р. [2] у ст. 14 «Юрисдикція» п. 4 також встановлено: «ця Конвенція не виключає жодної кримінальної юрисдикції, здійснюваної відповідно до національного законодавства». Отже, згідно з нормами цих конвенцій юрисдикція органів міжнародної юстиції вводиться тільки у тих випадках, коли національні правові системи не можуть чи не бажають здійснювати юрисдикцію. Також підкреслюється пріоритет органів національної юстиції стосовно міжнародних органів у випадках збігу юрисдикцій.

Отже, в основу діяльності органів міжнародної юстиції стосовно органів внутрішньодержавної юстиції покладено принцип комплементарності, який найбільш повно втілений у діяльності Міжнародного кримінального суду. Саме в силу комплементарності Міжнародний кримінальний суд, на думку професора Р. Ренні, у наш час являється «судом з дуже обмеженою юрисдикцією, а також з дуже обмеженим переліком категорій підсудних йому міжнародних злочинів». Основне завдання реального становлення Міжнародного кримінального суду (далі - МКС) полягає у тому, щоб його функціонування «успішно співіснувало з пріоритетним правом держав переслідувати міжнародних злочинців» [29].

У рамках Канцелярії (офісу) Прокурора Міжнародного кримінального суду була оприлюднена Стратегія обвинувачення, ухвалена у 2009 р., в якій була сформульована концепція позитивної комплементарності як політики активного співробітництва, націленої на стимулювання національної юрисдикції. За смислом Стратегії обвинувачення, «позитивний» підхід до комплементарности означає, що Офіс Прокурора буде заохочувати незалежні неупереджені розслідування злочинів у всіх країнах (у тому числі в державах, пов'язаних із ситуацією), підтримуючи активне співробітництво, але без залучення фінансових і технічних ресурсів. Допомога зі сторони Офісу повинна виражатися: а) у наданні інформації, зібраної Канцелярією, національним компетентним органам на їх вимогу відповідно до ст. 93 (п. 10) Статуту, при умові наявності локальної системи захисту суддів і свідків, що заслуговує довіри; б) у притягненні національних правоохоронних органів для участі у розслідуванні, що проводиться в рамках Канцелярії; в) у надан- 
ні інформації про розслідування Офісу органам, пов'язаним з посередницькою діяльністю, наприклад, спеціальним посланникам ООН з метою підтримання національних заходів у контексті розслідування; г) у сприянні проведення окремих організаційних заходів і налагодження контактів (п. 17).

Концепція позитивної комплементарності була включена в офіційні документи й увійшла до порядку денного Конференції держав-учасників по огляду Римського Статуту, проведеної в Кампалі (Уганда) з 31 травня по 11 червня 2010 р. [18].

Резолюція «Комплементарність» була однією 3 перших із загального числа всіх прийнятих актів даного форуму. В ній зазначалось, що учасники Конференції визнають: головну відповідальність держав у розслідуванні й припиненні серйозних злочинів, що викликають стурбованість світової спільноти (п. 1); необхідність здійснення додаткових заходів на національному рівні по організації допомоги зі сторони світової спільноти (п. 3); бажаність надання державами допомоги одна одній в укріпленні вітчизняного правопорядку та організації розслідування й кримінального переслідування міжнародних злочинів на національному рівні (п. 5) [5].

Концепція позитивної комплементарності отримала також своє зображення у прийнятих згодом стратегічних планах діяльності Офісу Прокурора на 2012-2015 та 2016-2018 pp. [6]. Вона активно дискутується закордонними вченими. 3 однієї сторони, передбачається, що «ідея інформування держав про попереднє розслідування Міжнародним кримінальним судом повинна заставити внутрішні органи нарощувати внутрішні зусилля для проведення власних національних розслідувань» [21], що «позитивна комплементарність являється інструментом для більшого укріплення внутрішньої юрисдикції» [33], який дозволить державам активно проводити власні розслідування з тим, щоб не залучити юрисдикцію МКС і не притягувати зайвої уваги зі сторони світової спільноти». К. Маршалл стверджує, що позитивна комплементарність повинна на практиці мати суттєвий ефект, оскільки «безпосереднє сприяння Міжнародного кримінального суду може впливати на запобігання здійсненню міжнародних злочинів, а також на укріплення національних судових установ» [27]. Між іншим, ця функція «попередження» обумовила виникнення в закордонній доктрині такого терміну як «попереджувальна» («proactive») стосовно до позитивної комплементарності. Так, у статті В. Бурк-Уайта «Proactive Complementarity: the International Criminal Court and National Courts in the Rome System of International Justice», опублікованій ще до прийняття Стратегіï 2009 р., при розгляді проблеми ефективності МКС, автор пропонує на рівні взаємодії національних судових установ і суду проводити політику «попереджувальної (proactive) комплементарності», яка передбачає розумний розподіл тягаря судового переслідування тяжких міжнародних злочинів між національними судовими органами та МКС [20].

Між тим, К. Хеллер стверджує, що позитивна комплементарність викликає серйозні побоювання з точки зору забезпечення справедливого суду і процесуальних прав обвинувачених на національному рівні [24, с. 255]. Річь у тому, що «активне» переслідування у власних державах для високопоставлених в минулому посадових осіб, може виявитися політично мотивованим чи бути упередженим (взяти, наприклад, судовий процес стосовно Симони Гбагбо в Кот-Д'Івуарі). 
I взагалі, як замітив Гліб Богуш, - «для більшості обвинувачених Міжнародний кримінальний суд в Гаазі, де гарантуються самі високі стандарти справедливого судового розгляду, а в списку покарань відсутня смертна кара, виглядає значно привабливіше національного судочинства» [11].

Висновки. Принцип комплементарності (доповнюваності) юрисдикцій виражений у міжнародно-правових актах, найбільш послідовно втілений у Статуті Міжнародного кримінального суду й полягає у тому, що органи міжнародної юстиції здійснюючи міжнародне правосуддя доповнюють національні органи кримінальної юстиції. Держави не передають якусь частину національного суверенітету, пов’язану з питаннями відповідальності та покарання осіб, що здійснюють злочини, які підпадають під юрисдикцію Суду. Юрисдикція органів міжнародної юстиції вводиться у тих випадках, коли держава не бажає (unwilling) чи нездатна (unable) вести розслідування чи порушувати кримінальне переслідування належним чином. Юрисдикція Міжнародного кримінального суду поширюється на злочини, здійснені на території держави-учасника чи громадянином цієї держави, що випливає з того факту, що Статут прийняв форму договору. Таким чином, у випадках збігу юрисдикцій між органом національної юстиції та органом міжнародної юстиції, перший 3 них, у принципі, має пріоритет. Міжнародні органи правосуддя не ставлять за мету підміняти національні суди. Принцип комплементарності має на меті гарантувати притягнення винних у самих серйозних злочинах осіб до відповідальності, що не може суперечити принципам і основам законодавства сучасних демократичних держав.

Принцип комплементарності вимагає усунення суперечностей між внутрішнім законодавством, у тому числі кримінально-процесуальним, і Статутом Міжнародного кримінального суду. Конституційні норми у більшості держав не допускають доповнення національної судової системи міжнародним судовим органом, проте принцип комплементарності не ставить у залежність національні органи кримінальної юстиції від Міжнародного кримінального суду.

\section{Jimepamypa:}

1. Конвенція $\mathrm{OOH}$ проти транснаціональної організованої злочинності, ухвалена Резолюцією 55/25 Генеральної Асамблеї від 15 листопада 2000 p. URL: http://zakon.rada.gov.ua/laws/ show/995_789

2. Конвенція Ради Європи про запобігання тероризму від 16 травня 2005 p. URL: http://zakon.rada.gov.ua/laws/show/994_712

3. Римський Статут Міжнародного кримінального суду від 17 липня 1998 р. (із змінами). Чинна редакція від 16 січня 2002 р. Документ 995_588 URL: http://zakon0.rada.gov.ua/laws/show/995_588

4. Устав Международного трибунала по бывшей Югославии. URL: http://www.un.org/ru/law/ icty/charter.shtml

5. Resolution RC/Res.1 «Complementarity» on 8 June 2010. Resolutions and Declarations adopted by the Review Conference. Review Conference of the Rome Statute of the International Criminal Court. Kampala, 31 May - 11 June 2010. Official Records, The Hague. P. 8.

6. Plan stratégique du Bureau du Procureur pour la période juin 2012-2015. Cour pénale international. Bureau du Procureur. URL: https://www.icc-cpi.int/en_menus/icc/ structure; Plan stratégique du Bureau du Procureur pour la période 2016-2018. Cour pénale international. Bureau du Procureur. URL: https://www.icc-cpi.int/iccdocs/ otp/Plan-strategique-2016-2018.pdf

7. Statute of the International Residual Mechanism for Criminal Tribunals. Security Council Resolution 1966(2010). URL: http://www.unmict.org/files/documents/statute/101222_sc_res1966_ statute_en.pdf 
8. Report of the Commission to the General Assembly on the work of its forty-sixth session. Yearbook of the International Law Commission 1994. A/CN.4/SER.A/1994/Add.l (Part 2). P. 45.

9. Правила процедуры и доказывания Международного уголовного суда. Документ ООН PCNICC/2000/1/Add.1.

10. Prosecutor v. Tihomir Blaskic, Appeals Chamber, Judgment on the Request of the Republic of Croatia for Review of the Decision of Trial Chamber II of 18 July 1997, 29 October 1997. Para. 47.

11. Богуш Г.И. MУС доверился Ливии. URL: https://zakon.ru/blog/2013/10/15/mus_doverilsya_ livii/R ating

12. Верле Г. Принципы международного уголовного права : учебник / пер. с англ. С.В. Саяпина. Одеса : Фенікс. Москва : ТрансЛит, 2011. 910 с.

13. Говорят свидетели защиты. Суд над Слободаном Милошевичем / под ред. Н.И. Рыжкова, В.Н. Тетекина. Москва : Вече, 2005.480 с.

14. Дремина Н.В. Принцип комплементарности юрисдикции Международного уголовного суда. Актуальні проблеми політики : Збірник наукових пращь. Вип. 26. Одеса : ПП «Фенікс», 2005.504 с. C.183-191.

15. Мезяев А.Б. Процесс против Слободана Милошевича в Гаагском Трибунале. Записки из зала суда. Обвинительная часть. Казань, 2006. Кн. 1.400 с.

16. Сафаров Н.А. Сотрудничество в области уголовного правосудия : «горизонтальная» и «вертикальная» модели. Международное уголовное правосудие : современные проблемы / под ред. Г.И. Богуша, Е.Н. Трикоз. Москва : Институт права публичной политики, 2009. 748 c.

17. Солера О. Дополнительная юрисдикция и международное уголовное правосудие. Международный журнал Красного Креста-2001: Сборник статей / пер. с англ. и фр. Москва : Международный комитет Красного Креста, 2002. С. 47-79.

18. Трикоз Е.Н. Кампальская конференция по международному уголовному правосудию. Международное уголовное право и международная юстииия. 2011. № 1. С. 20-23.

19. Benzing M. The Complementarity Regime of the International Criminal Court : International Criminal Justice Between State Sovereignty and the Fight Against Impunity. Max Planck Yearbook of U.N. Law. 2003. Vol. 7. P. 591-632.

20. Burke-White W.W. Proactive Complementarity : the International Criminal Court and National Courts in the Rome System of International Justice. Harvard International Law Journal. 2008. Vol. 49(1). P. 66-67.

21. Dancy G., Montal F. Unintended Positive Complementarity : Why International Criminal Court Investigations Increase Domestic Human Rights Prosecutions. Minnesota, 2015. P. 1-58.

22. Ferencz B.B. An International Criminal Code and Court : Where They Stand and Where They're Going. Columbia Journal of Transnational Law. 1992. Vol. 30. P. 375-399.

23. Jessberger F. Universality, Complementarity, and the Duty to Prosecute Crimes under International Law in Germany, in : International Prosecution of Human Rights Crimes / ed. W. Kaleck, M. Ratner, T. Singelnstein, P. Weiss. 2007. P. 213

24. Heller K.J. The Shadow Side of Complementarity : The Effect of Article 17 of the Rome Statute on National Due Process. International Criminal Law Forum. 2006. Vol. 17(3). P. 255.

25. Kleffner J. The Impact of Complementarity on National Implementation of Substantive International Criminal Law. Journal of International Criminal Justice. 2003. Vol. 1. № 1. P. 86-113;

26. Köchler H. Universal Jurisdiction and International Power Politics : Ideal versus Real. Yeditepe'de Felsefe, Istanbul, 2006. P. 1-20.

27. Marshall K.A. Prevention and Complementarity in the International Criminal Court: A Positive Approach. Human Rights Brief Online. URL: http://www.wcl.american.edu/hrbrief/17/2marshall.pdf

28. Ryngaert C. Horizontal Complementary Jurisdiction of Bystander States in the Prosecution of International Crimes under the Universality Principle. Leuven Centre for Global Governance Studies. 2010. P. 1-30.

29. Rennie R.I.M. The International Criminal Court : A Contextual Study of s Nascent Court within the International Criminal Legal System: thesis ... degree of LL.M. / R.I.M. Rennie. Dalhousie University, 2003.

30. Cassese A. International Criminal Law. 2nd ed. 2008. P. 336; Essays on the Rome Statute of the International Criminal Court / P. Benvenuti, F. Lattanzi, W. Schabas (eds.)/ 1999. Vol. 1. P. 21.

31. Cameron I. Jurisdiction and Admissibility Issues Under The ICC Statute. The Permanent International Criminal Court / D. McGoldrick, P. Rowe, E. Donelly. (eds). Oxford. 2005. P. 65-94. 
32. Clapham E. Issues of Complexity, Complicity and Complementarity : From the Nuremberg Trials to the Dawn of the New International Criminal Court // From Nuremberg to The Hague. The Future of International Criminal Justice / Ed. by P. Sands. Cambridge, 2003. P. 20-67;

33. Stahn C. Taking Complementarity Seriously. International Criminal Court and Complementarity / ed. C. Stahn, M.M. El Zeidy. Cambridge : Cambridge University Press. 2011. Vol 1. P. 233- 282.

34. Williams S.A., Schabas W.A. Article 17 : Issues of Admissibility / ed.O. Triffler. Commentary on the Rome Statute. 2nd ed. 2008. P. 608.

\section{Анотація}

Попко В. В. Принцип комплементарності у міжнародному кримінальному праві. - Стаття.

У статті досліджується принцип комплементарності юрисдикцій у міжнародному кримінальному праві, зокрема співвідношення юрисдикцій національних і міжнародних кримінальних судових органів, що останнім часом активно обговорюється у доктрині міжнародного кримінального права. Увагу автора привертає формування принципу комплементарності, його моделі, концепція, втілення у міжнародно-правових актах та діяльності органів міжнародної юстиції у зв'язку зі зростанням транснаціональної злочинності. Автор розглядає моделі співвідношення міжнародної та національної юрисдикцій, що складись у міжнародних відносинах у зв’язку із діяльністю органів міжнародної кримінальної юстиції. Автор розглядає концепції «горизонтальної», «вертикальної» та "паралельної» комплементарності стосовно взаємодії національних судів держав і Міжнародного кримінального суду. Особлива увага приділяється моделі, що базується на принципі комплементарності, який закріплений у Римському статуті Міжнародного кримінального суду, що обумовило детальний аналіз норм Римського Статуту, які стосуються даних відносин.

Ключові слова: принцип комплементарності, міжнародна юрисдикція, національна юрисдикція, кримінальна юстиція.

\section{Аннотация}

Попко В. В. Принцип комплементарности в международном уголовном праве. - Статья.

В статье исследуется принцип комплементарности юрисдикций в международном уголовном праве, в частности соотношение юрисдикций национальных и международных уголовных судебных органов, что в последнее время активно обсуждается в доктрине международного уголовного права. Внимание автора привлекает формирование принципа комплементарности, его модели, концепция, воплощение в международно-правовых актах та деятельности органов международной юстиции в связи с ростом транснациональной преступности. Автор рассматривает модели соотношения международной и национальной юрисдикций, что сложились в международных отношениях в связи с деятельностью органов международной уголовной юстиции. Автор рассматривает концепции «горизонтальной», «вертикальной» и «параллельной» комплементарности относительно взаимодействия национальных судов государств и Международного уголовного суда. Особенное внимание уделяется модели, которая базируется на принципе комплементарности, закрепленном в Римском Уставе Международного уголовного суда, что обусловило детальный анализ норм Римского Устава, которые касаются данных отношений.

Ключевые слова: принцип комплементарности, международная юрисдикция, национальная юрисдикция, уголовная юстиция.

\section{Summary}

Popko V. V. Complementarity principle in international criminal law. - Article.

The article examines the principle of complementarity of jurisdictions in international criminal law, in particular the relationship between the jurisdictions of national and international criminal justice, which has recently been actively discussed in the doctrine of international criminal law. The author pays attention to the formation of the principle of complementarity, its model, concept, implementation in international legal acts and the activities of international justice bodies in connection with the growth of transnational crime. The author examines the model of correlation of international and national jurisdictions in international relations in connection with the activities of the bodies of international criminal justice. The author considers the concept of "horizontal", "vertical" and "parallel" complementarity with regard to the interaction of national courts of States and the International Criminal Court. Particular attention is paid to the model based on the principle of complementarity, which is enshrined in the Rome Statute of the International Criminal Court, which led to a detailed analysis of the rules of the Rome Statute, which relate to these relations.

Key words: principle of complementarity, international jurisdiction, national jurisdiction, criminal justice. 